\section{Aleksandra S. Maksimović}

Visoka škola strukovnih studija za vaspitače,

Šabac

Nebojša M. Macanović*

Univerzitet u Banjoj Luci,

Fakultet političkih nauka doi: 10.19090/zop.2017.26.175-187

UDC: $37: 303.022$

37:303.621.32

Pregledni rad

\title{
INTERVJU U KVALITATIVNIM PEDAGOŠKIM ISTRAŽIVANJIMA
}

Apstrakt. Metodološka i epistemološka pitanja čine konstitutivne elemente svake nauke. Tokom razvoja pedagoške nauke otvarale su se brojne dileme koje se odnose na primenu najadekvatnije metodologije za izučavanje fenomena vaspitanja i obrazovanja. Poslednjih nekoliko decenija posebno se analizira pitanje primene kvalitativnih istraživanja $u$ pedagogiji. $U$ ovom radu ispituje se pitanje primene intervjua u kvalitativnim pedagoškim istraživanjima. Pri tome su navedena terminološka određenja kvalitativnih istraživanja, definicije, kao i vrste intervjua. Posebna pažnja posvećena je ispitivanju prednosti i nedostataka vezanih za primenu intervjua u kvalitativnim pedagoškim istraživanjima, dok je u zaključku ukazano na prednosti triangulacije za obuhvatnije ispitivanje pedagoške problematike.

Ključne reči: intervju, kvalitativna istraživanja, pedagoška istraživanja.

\section{UVOD}

Metodološka i epistemološka pitanja predstavljaju konstitutivne elemente svake nauke, pa i pedagogije. Tokom razvoja pedagoške nauke javljale su se različite dileme u pogledu primene adekvatne metodologije istraživanja. Pitanje koje se razmatra u ovom radu odnosi se na primenu intervjua $\mathrm{u}$ kvalitativnim pedagoškim istraživanjima. $U$ tom kontekstu otvaraju se i dileme koje se tiču specifičnosti predmeta proučavanja pedagogije i primene kvalitativne metodologije (Matović, 2007; Šekvušić, 2011). Naime, s obzirom na fenomene koji su u fokusu ispitivanja pedagoške nauke, od sredine $\mathrm{XX}$ veka sve više se insistira na interpretaciji i

\footnotetext{
*Nebojša Macanović, nebojsa.macanovic@fpn.unibl.org
} 
razumevanju proučavanih pojava (Banđur, 1999), odnosno traganju za značenjem u društvenim naukama (Fajgelj, 2014). Sa tim vezi otvara se i dilema kako se definišu kvalitativna istraživanja. Halmi (2005) daje opštu definiciju kvalitativnih istraživanja kao multiparadigmatski i multimetodološki usmerenih istraživanja koja uključuju naturalistički i interpretativni pristup predmetu istraživanja. Princip otvorenosti prema predmetu istraživanja postavljen je kao osnovna karakteristika kvalitativnih istraživanja, jer bez ove otvorenosti nije moguća čista deskripcija a time ni smislena interpretacija (Rein, 1980 prema Halmi, 2005: 26). Još neke odlike kvalitativnih istraživanja, i to više heurističkog nego normativnog značenja, jesu: holistički pristup; istraživanje ilustruje odnos između sistema ili kultura; odnos licem u lice između istraživača i ispitanika; permanentno i višekratno prisustvo na terenu $\mathrm{i}$ istovremeno proporcionalno provedeno vreme $\mathrm{u}$ analizi podataka; istraživač je instrument istraživanja; sjediniti odluke koje se tiču istraživanja sa etičkim pitanjima... (Halmi, 2005). Šerman i Veb (Shermann \& Webb, 2005) pristupaju kvalitativnim istraživanjima u pedagogiji kao specifičnoj filozofiji obrazovanja. Naime, ovi autori ističu da personalističkofenomenološka filozofija obrazovanja u centar postavlja individuu i pitanja koja se odnose na njeno viđenje stvarnosti. U sličnom duhu, Viling (2016) ističe da su kvalitativni istraživači, pre svega, zainteresovani za značenje, za to kako ljudi pridaju smisao svetu i kako doživljavaju sve što im se dešava, odnosno za značenja koja sami učesnici istraživanja pripisuju događajima.

Ipak, i pored ukazivanja na značaj primene kvalitativnih istraživanja u pedagogiji, Šekvušić uočava da su u domaćoj relevantnoj literaturi više zastupljeni pregledni radovi u kojima se analiziraju različite kvalitativne metode nego izveštaji o pedagoškim istraživanjima u kojima su te metode primenjene i ukazuje da to može biti ,pokazatelj da se kvalitativne metode još uvek bore za ravnopravan status sa kvantitativnim metodama“ (Šekvušić, 2011: 60).

\section{DEFINICIJE INTERVJUA}

Jedna od najčešće korišćenih istraživačkih tehnika u kvalitativnim istraživanjima je intervjuisanje (Anderson, 2005; Knežević Florić i Ninković, 
2012). Koen, Manion i Morison (Cohen, Manion \& Morrison, 2007) naglašavaju da je intervju veoma primenjen način prikupljanja podataka $u$ pedagoškim naukama: iako intervjuisanje zahteva mnogo vremena, otvara pristrasnosti istraživača, i može biti nezgodno za ispitanika, istraživači ga često koriste.

Pri tome, intervju je široko raspostranjena metoda za prikupljanje podataka od medijskih do policijskih intervjua. Ipak, postoje norme koje se odnose na razlike između raznovrsnih intervjua koji se obavljaju u različitih delatnostima i intervjua u nauci (Fajgelj, 2014).

U tom kontekstu, karakteristično je da primena intervjua - kao metoda za prikupljanje podataka u društvenim naukama - na prvi pogled deluje kao nešto svima poznato, dok pri tome nije lako definisati šta je intervju (Fajgelj, 2014). Mužić (1973) određuje intervju kao plansko izazivanje verbalnih manifestacija ličnosti sa kojom razgovaramo, da bismo time došli do novih spoznaja u pedagogiji. Pedagogu istraživaču cilj je da sagleda nove naučne spoznaje, da uoči zakonitosti u pedagoškim pojavama otkrivanjem novih kauzalnih veza.

Banđur i Potkonjak (1999) intervju određuju kao unapred pripremljen i planiran tematski razgovor između istraživača i intervjuisanih. Istraživač usmeno postavlja pitanja radi prikupljanja činjenica relevantnih za predmet istraživanja i nastoji da sa subjektom vodi razgovor ka unapred definisanom cilju - dolaženju do određenih informacija. Intervjuom se prikupljaju podaci do kojih se teško može doći, ili uopšte ne može, drugim istraživačkim tehnikama, a odnose se na mišljenja, stavove, želje, interesovnja i preferencije ispitanika (Banđur i Potkonjak, 1999). Kvin Paton (Quin Patton, 2002: 180) intervju vidi kao način povezivanja osoba, te navodi da je svrha intervjua da nam omogući da upoznamo perspektivu druge osobe, da vidimo tuđe mišljenje i da čujemo „stranu priče“ druge osobe. Dobar intervju određen je i kao veza i interakcija (Quin Patton, 2002). Slično, i Mišer (Misher, 1986) smatra da je suština intervjua u tome da dve osobe razgovaraju. Uz to, značajno je kako se bavimo reprezentacijom i analizom procedure intervjua koji čini vezu između diskursa i značenja: 1) intervju je događaj govora; 2) diskurs intervjua zajednički konstruišu istraživač i 
ispitanik; 3) analiza i tumačenje zasnivaju se na teoriji diskursa i na smislu; 4) značenja pitanja i odgovora jesu kontekstualno zasnovana (Misher, 1986).

Fajgelj definiše intervju kao naučnu metodu: „kao merni istrument u naukama o ponašanju“ (Fajgelj, 2014: 356). To znači da se odgovori ispitanika moraju prevesti u mere određenih svojstava, varijable koje su predmet istraživanja. Deatljnije opisujući šta je intervju. Fajgelj akcentuje da je jasno da se intervju zasniva na komunikaciji između dve strane: intervjuera i intervjuisane osobe. Intervju predstavlja razgovor, ili jezik znakova, ukoliko se vodi sa gluvonemom osobom. Takođe, intervju ne mora biti vođen licem u lice, nego i telefonom ili komunikacijom putem interneta. Uz to, intervju ne mora biti samo razgovor, nego se značajno posmatra i beleži i ponašanje učesnika, neverbalna komunikacija koja je u nekim slučajevima važniji izvor podataka od reči. Reči koje dobijemo kao odgovore na postavljeno pitanje $u$ intervjuu, sa druge strane, ne moraju biti analizirane samo u odnosu na njihovo značenje, nego i frekfenciju ili naglašavanje.

U skladu sa ranije navedenim zapažanjima, Milas smatra da je potrebno razgraničiti određivanje intervjua u nauci i njegovih drugačijih primena i saglasan je sa opisom intervjua kao „razgovora sa svrhom“ (Bingham, Moore, 1924; Babbie, 1992; Nachmias, Nachmias, 1992; Berg, 1996 prema Milas, 2005: 585). Milas (Milas, 2005) smatra da je naučni intervju razgovor dve osobe koji je podstakao intervjuer s ciljem prikupljanja informacija važnih za istraživački problem. Ispitanik se pita za stavove, mišljenja, iskustva i osećanja, ali ne postoji direktna namera da se na njega utiče, kao što je to slučaj u kliničkom intervjuu.

Vidimo da su definicije intervjua šarolike i da su savremene definicije obuhvatnije u značenju, te se, osim tradicionalnog razgovora, sada uključuje sveobuhvatna komunikacija, verbalna i neverbalna, kao i različiti načini sposrazumevanja između istraživača $i$ ispitanika. Ipak, za sve odrednice intervjua zajedničko jeste da u prvi plan stavljaju komunikaciju između ljudi. Stoga se i kao svrha intervjua izdvaja ostvarivanje komunikacije. 


\section{VRSTE INTERVJUA}

Osim definisanja intervjua, značajno je i pitanje podele intervjua na različite vrste. U tom kontekstu, potrebno je naglasiti da ove podele uključuju različite norme. Na primer, Mužić (1973) intervjue deli na osnovu nekoliko kriterijuma. Na osnovu sadržaja i toka, piše o vezanom i slobodnom intervjuu. U vezanom su pitanja unapred precizirana, doslovno ili samo sadržajno. Slobodni intervju je sličniji diskusiji u kojoj se ispitanik podstiče da analizira svoje poglede o određenom pitanju. Drugi kriterijum odnosi se na osobe koje se intervjuišu, odnosno da li je u pitanju direktni intervju kada se razgovara sa ličnošću čije ponašanje i stavove ispitujemo, i indirektni intervju - kada u razgovoru sa okolinom dobijamo podatake o nekoj osobi. $\mathrm{Na}$ osnovu broja ispitanika sa kojima se simulatno razgovara, razlikuju se individualni (razgovor sa jednom osobom) i kolektivni intervju (simultani razgovor sa većim brojem osoba). Slično, Banđur i Potkonjak (1999) intervjue dele na vezane i slobodne i individualne $i$ grupne.

Anderson piše o dve grupe intervjua: 1) normativni - prikupljanje podataka koji se klasifikuju i analiziraju statistički i 2) ključni - kada istraživači žele da ispitaju viđenje o određenom pitanju male grupe ispitanika (Anderson, 2005).

Jednu od najdetaljnijih podela intervjua daju Koen, Manion i Morison koji pišu o: 1) standardizovanom, 2) dubokom, 3) etnografskom, 4) elitnom, 5) intervjuu-životne priče, 6) fokus-grupnom, 7) polustrukturisanom, 8) grupnom, 9) strukturisanom, 10) objašnjavajućem, 11) neformalnom, 12) otvorenom i 13) zatvorenom intervjuu (Cohen et al. 2007). Sa druge strane, Kvin Paton (Quin Patton, 2002) navodi nešto drugačiju klasifikaciju intervjua: 1) informalni konverzacioni intervju - najotovreniji intervju, a to što je nestrukturisan ne znači da razgovor nije fokusiran; ipak, kao slabost ovog intervjua, pojavljuje se teškoća pri analizi različitih odgovora koje dobijamo na različita pitanja; 2) „upitni intervju“ - sastoji se od liste pitanja koja će biti postavljena i objašnjenja tokom intervjua; 3) zatvoreni intervju sa fiksnim, ponuđenim odgovorima.

U savremenoj relevatnoj literaturi se kao vrste intervjua najčešće navode strukturisani i nestruktruisani, odnosno standardizovani i 
nestandardizovani (Fajgelj, 2014). Pri tome se ukazuje i na potreb korišćenja polustrukturisanog intervjua, koji je uočen i kao najčešće korišćena metoda prikupljanja podataka u kvalitativnim istraživanjima u psihologiji (Viling, 2016), kao i u ispitivanju pedagoške problematike (Radišić, Stanković i Jošić, 2016).

U tom kontekstu navodimo podelu Desi i Poter (Desai \& Potter, 2006) koji pišu o strukturisanom, polusturukturisanom i nestrukturisanom intervjuu. Za strogo strukturisani intervju karakteristično je postojanje liste pitanja koja služi kao osnova razgovora, unapred postavljena veoma detaljano. Polustrukturisani intervju ima u sebi nekoliko tema, predloženih za diskusiju, ali ove teme i pitanja razvijaju se dalje tokom intervjua. Nestrukturisani intervju odslikava konverzaciju koja nije direktivno usmerena od strane istraživača, potpuno je otvorena i ispitanici imaju najveću slobodu. Izbor vrste intervjua zavisi od vrste istraživanja.

Slično, Halmi (Halmi, 2005) smatra da prema nivou strukturisanosti postoje tri kategorije intervjua: 1) otvoreni ili nedirektivni, u kojem ispitanici imaju visok stepen slobode; 2) nestrukturisani ili nestandardizovani, koji se odnosi na nivo slobode istraživača, koji nema spisak pitanja, nego ih formira $u$ zavisnosti od situacije; 3) kvalitativni, koji se odnosi na vrednovanje intervjuisanog materijala koje se obavlja interpretativnim tenikama.

Interesantno je da Milas (Milas, 2005) standardizovani intervju vidi kao predstavnika kvantitativne metodologije, za razliku od dubinskog, koji se javlja u kontekstu kvalitativne paradigme. Pod pojmom dubinskog, usmerenog intervjua podrazumevaju se svi oblici otvorenog, polustrukturisanog ispitivanja. Osnovna zamisao takvih intervjua sastoji se $u$ tome da se ispitanik dovede u situaciju da se spontano izjašnjava o svojim mišljenjima, stavovima, osećanjima i razlozima svog ponašanja u vezi sa problemom koji se istražuje. U tim situacijama razgovor je usmeren na prethodno postavljen problem, ali ispitivanje se ne obavlja na osnovu postavljanja pitanja nego što više spontano, „samo od sebe“ (Halmi, 2005: 320). Za realizaciju problemski usmerenog intervuja bitna je otvorenost koja znači i da nema unapred ponuđenih odgovora ispitanicima. Prednosti ovog pristupa su u tome što istraživač odmah može proveriti da li je ispitanik razumeo pitanje; učesnici mogu pokazati subjektivne perspektive; mogu 
razvijati sadržaj veće kognitivne strukture; konkretni uslovi situacije intervjua mogu se tematizovati. Za vođenje ovakvog razgovora, koji odslikava dubinski usmeren intervju, sugerisano je da se sastoji od prvobitnog postavljanja opštih pitanja pomoću kojih se postupno ulazi u problematiku, prelaženja na tematska pitanja koja se sve više usmeravaju prema ključnom pitanju i istovremenog verodostojnog beleženja razgovora (Halmi, 2005). Temeljna odrednica dubinskog intervjua jeste heuristički pristup, odnosno potraga za novim spoznajama ili razvijanje zamisli i istraživačkih hipoteza koje teže razumevanju načina na koje ljudi razmišljaju i osećaju o određenom problemu. Za razliku od standardizovanog intervjua $u$ kojem se tačno zna šta se želi pa se ispitanici vode uvek u istom smeru, dubinski intervju usredsređen je uglavnom na otvaranje novih perspektiva i sticanja potpunijeg uvida u dotadašnja neistražena područja.

Narativni intervju je takođe jedan od oblika intervjua i veoma je malo standardizovan. Osnovna ideja jeste da postoje subjektivne strukture značenja koje dolaze do izražaja u slobodnoj naraciji. Ovo je veoma karakteristično za metode životnih priča (life stories). Ova kvalitativna tehnika primenjuje se onda kada se može stimulisati pripovedanje (Halmi, 2005).

Osim opisanih vrsta intervjua u analiziranoj literaturi naglašeno je da je poslednjih godina i fokus-grupni intervju uspostavljen kao standardna tehnika prikupljanja podataka u kvalitativnim istraživanjima (Đurić, 2007; Fajgelj, 2014; Knežević Florić i Ninković, 2012; Milas, 2005; Radišić i sar. 2016; Viling, 2016). Pri tome se posebno insistira na distinkciji između grupnog i fokus-grupnog intervjua: osnovnu razliku predstavlja grupna dinamika, interakcija u grupi koja se koristi kao značajan izvor podataka o ispitivanom problemu.

\section{PREDNOSTI I TEŠKOĆE PRIMENE INTERVJUA U KVALITATIVNIM PEDAGOŠKIM ISTRAŽIVANJIMA}

Analizirajući primenu intervjua $\mathrm{u}$ kvalitativnim pedagoškim istraživanjima, potrebno je ukazati na prednosti i teškoće koje prate taj proces. Kao prednosti korišćenja intervjua $u$ pedagoškim ispitivanjima istaknute su: prilika za bogat izvor podataka, mogućnost uvida u ispitanikove 
intimne stavove, želje, očekivanja, praćenje neverbalne komunikacije, mogućnost celovite analize istraživačkog problema. Intervju je pogodan metod za prikupljanje podataka jer su ispitanici više angažovani nego pri popunjavanju ankete, te se pretpostavlja da su odgovori koje daju u intervjuu obuhvatniji. Prikom intervjuisanja istraživač može da pojasni pitanje i time olakša odgovor ispitanika. Intervju omogućava istraživaču da uoči neverbalne reakcije kao što su izraz lica ili promena glasa i da ove reakcije poveže sa kontekstom u kojem se javljaju (Anderson, 2005). Osim toga, primenom intervjua omogućeno je obuhvatanje relativno široke populacije (nepismenih osoba, dece predškolskog uzrasta...) u odnosu na populaciju koju je moguće obuhvatiti anketiranjem (Havelka, Kuzmanović i Popadić, 2008; Knežević Florić i Ninković, 2012). U sličnom duhu, istraživači smatraju da je intervju adekvatan za sakupljanje podataka jer omogućava brojne kanale komunikacija: verbalne, neverbalne, govorne, čujne... (Cohen et al. 2007).

Prednost intervjua jeste $\mathrm{i}$ to što je uočen i kao dinamični socijalni momenat: razmena mišljenja, naglašena interakcija $u$ formiranju znanja tokom prikupljanja podataka omogućava diskusiju o različitim interpretacijama problema. Istraživači koji daju prednost intervjuu naglašavaju da treba sagledati interpersonalni, interakcioni, komunikativni i emocionalni aspekt intervjua i da uspešan intervju zahteva dinamičnu i intenzivnu interakciju (Cohen et al. 2007).

Opisujući dobre strane primene intervjua, relevatni autori naglašavaju da se, osim prikupljanja činjenica, na ovaj način ispituju i uverenja o tim činjenicama, objašnjava sadašnje ili prošlo ponašanje ispitanika, identifikuju se njihova osećanja i motivi koji se odnose na predmet ispitivanja (Cohen et al. 2007). Kao prednosti intervjua izdvojene su: neposredan kontakt između učesnika, veći stepen međusobog poverenja i saradnje, veći stepen iskrenosti i tačnosti iskaza (Banđur i Potkonjak, 1999), kao i što se time u nekim situacijama omogućava ispitanicima da diskutuju o stvarima koje ranije nisu mogli nikome da kažu (Desai \& Potter, 2006).

Sa druge strane, kao nedostaci intervjua navode se situacije kada prilikom intervujisanja isptanici daju poželjne odgovore, pričaju ono što se od njih očekuje umesto istine, validnost istraživanja često zavisi od veštine 
istraživača, intervju dugo traje, ova tehnika je skupa, a takođe je i teško uvek jasno analizirati dobijene podatke (Anderson, 2005). Kao slabe stane intervjua istaknute su i mali broj ispitanika koji su obuhvaćeni i problem otpora učesnika prema dokumenatovanju intervjua putem beleženja i snimanja razgovora (Banđur i Potkonjak, 1999). Kao još jedan nedostatak, uočena je i situacija u kojoj kvalitet odgovora na istraživačka pitanja zavisi od ispitanika. Takođe, kontekst koji utiče na odgovore može biti povezan sa trenutkom u kojem se odigrava intervju (Anderson, 2005). Osim toga, prilikom intervjuisanja može doći i do ,gubljenja podataka“ jer je teško zabeležiti sve informacije, posebno ako se samo piše (Knežević Florić i Ninković, 2012).

Pitanje pouzdanosti tj. relijablnosti $u$ intervuju otvoreno je više puta $u$ relevantnoj literaturi. Uz to, ukazuje se i na problem prisnosti istraživača (Fajgelj, 2014). Izvori pristrasnosti i predrasuda jesu stavovi istraživača, ispitanika, materijalni sadržaji pitanja (stavovi, mišljenja, očekivanja, stavovi osobe koja intervjuiše, tendencija istraživača da vidi razgovor iz svog ugla, tendencija istraživača da traži odgovore koji podržavaju unapred zamišljene predstave, nerazumevanje ispitanika o onome što je istraživač pitao, nesporazumi o tome šta se traži od ispitanika...). Intervjuista može povećati ili smanjiti želju istitanika da se otvori, može doći do (kontra)transfera i projektovanja želja, osećanja, strahova (Cohen et al. 2007).

Osim toga, otvaraju se i etičke dileme koje prate intervjuisanje a odnose se na: 1) saglasnost i informisanost ispitanika pre prikupljanja podataka o tome da su učesnici potpuno upoznati sa istraživanjem i da pristaju da učestvuju u njemu, 2) istraživač mora garantovati i obezbediti poverljivost dobijenih podataka, 3) obmanjivanje ispitanika nije dopušteno, 4) učesnici imaju pravo na odustajanje bez ikakvih posledica, 5) po okončanju istraživanja ispitanike koji su u njemu učestvovali potrebno je izvestiti o dobijenim nalazima i publikacijama nastalim na osnovu rezultata ispitivanja (Viling, 2016). Uz to, potrebno je uvažiti i posebne etičke obzire prema deci jer su u pedagoškim istraživanjima i deca ispitanici. Saglasnost za učešće dece $i$ mladih $u$ istraživanju treba dobiti $i$ od deteta $i$ od roditelja/staratelja; istraživač mora da uspostavi adekvatan odnos prema deci kao učesnicima istraživanja i da obezbedi da se prevaziđu uzrasne i statusne 
nejednakosti između istraživača i dece kao učesnika; zaštita podataka i identiteta učesnika predstavlja poseban izazov u slučajevima kada su deca ispitanici (Đurić, 2012).

\section{ZAVRŠNA RAZMATRANJA}

$\mathrm{U}$ ovom radu analizirana je primena intervjua $\mathrm{u}$ kvalitativnim pedagoškim istraživanjima. Ispitujući stanovišta o intervjuu kao metodi ispitivanja u pedagogiji. uočeno je da različiti autori na drugačije načine pristupaju intervjuu, da su definicije intervjua šarolike i da su savremene definicije obuhvatnije u značenju, pa se osim tradicionalnog razgovora sada uključuje sveobuhvatna komunikacija, verbalna i neverbalna, kao i različiti načini sporazumevanja između istraživača i ispitanika. Ipak, za sve odrednice intervjua zajedničko je to da u prvi plan stavljaju komunikaciju između ljudi i da se kao svrha intervjua određuje ostvarivanje uspešne interakcije i komunikacije.

Poput različitih pristupa definisanju pojma intervjua, prisutne su i razlike u određivanju vrsta intervjua. Ipak, u savremenoj literaturi preovlađuje podela na strukturisani, polustruktirsani i nestrukturisani intervju. Polustrukturisani intervju se pri tome ističe kao najadekvatnija metoda prikupljanja podataka u kvalitativnim istraživanjima u pedagogiji.

Analiza prednosti i nedostataka primene intervjua u kvalitativnim pedagoškim istraživanjima pokazala je da se kao dobre strane ove metode ističu: mogućnost obuhvata široke populacije, fleksibilnost i prilagođavanje sagovorniku, prikupljanje podataka o verbalnim i neverbalnim reakcijama ispitanika, opširnost dobijenih odgovora, dok su kao nedostaci uočeni: neekonomičnost, pristrasnost istraživača, mogućnost da se ne zabeleže svi potrebni podaci...

Ali, jedan od načina prevazilaženja ovih teškoća i postizanja validnosti i pouzdanosti intervjua jeste upoređivanje podataka dobijenih $u$ intervjuu sa drugim podacima koji su već provereno validni, odnosno primena triangulacije u metodološkom pristupu. Kombinacija više metoda daje tačniji prikaz fenomena istraživanja, a korišćenjem različitih tehnika i 
metoda za sakupljanje informacija doprinosi se većoj pouzdanosti i kredibilitetu istraživanja i obezbeđuju različiti pristupi predmetu istraživanja.

\title{
AN INTERVIEW IN QUALITATIVE EDUCATIONAL RESEARCH
}

\begin{abstract}
Methodological and epistemological questions are constituent elements of any science. During the development of pedagogical science there have existed numerous dilemmas related to the application of the most appropriate methodology in educational research. In the last several decades, the application of qualitative research in pedagogy has been analyzed. The paper examines the issue that refers to the application of interviews in qualitative educational research. There have been presented different terminological definitions of qualitative research as well as several types of the interviews. A special attention is given to the examination of advantages and disadvantages related to the application of interviews in qualitative educational research, while the conclusion points to the benefits of triangulation for a more comprehensive examination of pedagogical problems.
\end{abstract}

KEY WORDS: interview, qualitative research, educational research. 


\section{REFERENCE}

Anderson, G. (2005). Fundamental of educational research. Taylor \& Francis e-Library.

Banđur, V. i Potkonjak, N. (1999). Metodologija pedagogije. Beograd: Savez pedagoških društava Jugoslavije.

Cohen, L., Manion, L. \& Morrison, K. (2007). Research Methods in Education. Oxon: Routledge, Taylor \& Francis Inc.

Desai, V. \& Potter, R. (2006). Doing development research. Sage Publication, Inc.

Đurić, S. (2007). Fokus-grupni intervju. Beograd: Službeni glasnik.

Đurić, S. (2012). Etički problemi u istraživanjima o deci. Specijalna edukacija i rehabilitacija, 11 (3), 449-468.

Fajgelj, S. (2014). Metode istraživanja ponašanja. Beograd: Centar za primenjenu psihologiju.

Halmi, A. (2005). Strategije kvalitativnih istraživanja u primenjenim društvenim znanostima. Jasterbarsko: Naklada Slap.

Havelka, N., Kuzmanović, B. i Popadić, D. (2008). Metode i tehnike socijalnopsiholških istraživanja. Beograd: Centar za primenjenu psihologiju.

Knežević Florić, O. i Ninković, S. (2012). Horizonti istraživanja $u$ obrazovanju. Novi Sad: Filozofski fakultet, Odsek za pedagogiju.

Maykut, P. \& Morehouse, R. (2005). Beginning Qualitative Research. Taylor $\&$ Francis e-Library.

Milas, G. (2005). Istraživačke metode u psihologiji $i$ drugim društvenim znanostima. Jasterbarsko: Naklada Slap.

Misher, G. E. (1986). Research Interviewing - Context and Narrative. President and Fellows of Harvard College.

Mužić, V. (1973). Metodologija pedagoških istraživanja. Sarajevo: Zavod za izdavanje udžbenika.

Quin Patton, M. (2002). Qualitative research and evaluation methods. Sage Publication, Inc.

Radišić, J., Stanković, D. i Jošić, S. (2016). Akciona istraživanja kao oruđe za unapređivanje nastave i učenja. U S. Maksić i I. Đerić (Ur.), Razvoj 
istraživačke prakse u školi (str. 37-54). Beograd: Institut za pedagoška istraživanja.

Shermann, R. R. \& Webb, R. B. (2005). Qualitative Research in Education: Focus and Methods. Taylor \& Francis e-Library.

Viling, K. (2016). Kvalitativna istraživanja u psihologiji. Beograd: Clio. 